\title{
The Impacts of Tri Hita Karana - Based Educational Tourism
}

\author{
Ni Nyoman Parwati ${ }^{1}$, I Nengah Suparta ${ }^{2}$, I Made Mariawan ${ }^{3}$ \\ ${ }^{1,2,3}$ Faculty of Mathematics and Science \\ Universitas Pendidikan Ganesha \\ Singaraja, Indonesia \\ 1nyoman.parwati@undiksha.ac.id, 2nengah.suparta@undiksha.ac.id, ${ }^{3}$ made.mariawan@undiksha.ac.id
}

\begin{abstract}
This study was aimed at analyzing and describing the impacts of Tri Hita Karana-Based Educational Tourism on the quality of the community life. This descriptive qualitative research was done to the communities of Mengesta Village. The subjects consisted of 60 community members involved as the learning resource persons in developing the educational tourism. The data which were collected consisted of the impact of the development of educational tourism on the improvement of the community life quality. The data were collected by using questionnaire and field observation. The data was analyzed descriptively and qualitatively. The result showed that the average of the respondents' responses related to the impact of the development of the educational tourism on the social community life was $88 \%$, falling into "positive" minimal qualification. There was an increase in the local economy with the average of $55 \%$.
\end{abstract}

\section{Keywords-educational tourism, Tri Hita Karana, quality of community life}

\section{INTRODUCTION}

Tourism business is a motivating sector for the national economy, especially in Bali. The growth of businesses in tourism sector has an impact on the development of other business sectors, which include hotel, traveling, souvenir, and transportation. Tourism in principle has three main pillars, that are, government, private organizations, and the community. The community is one of the main pillars in developing tourism, because whatever policy made by the government and whatever support given by the private organizations as the providers of facilities if they are not supported by the community in the environment tourism will not develop optimally [1] [2]. However, to develop a community's awareness of the importance of tourism is not easy. According to [3] [4] there are some types of tourism development, which include (a) the whole with a new goal, for example, to build attractions in the site which was formerly not used for attraction; and (b) to create new activities or stages of an activity that is going to be relocated to another, in which the activity needs modifications in building and structure.

Along with the increasingly more rapid development of tourism in Bali, social problems start to surface. One of them is the decrease in the agricultural land which causes the decrease in the farmers' income. Land conversion cannot be stopped along with the development of the tourism sector. The nature which was formerly a tourist attraction, such as rice field terraces, mounts, beaches, now starts to have new functions as villa, hotel, restaurant, and residential areas [5]. Other problem which recently started to be felt is local wisdoms which the community hold high start to fade away [1]. This problem also occurs in the agricultural region / the subak of Mengesta Village, Tabanan regency, which belongs to World Cultural Heritage (WCH) of Jatiluwih.

Mengesta is a village that belongs to $\mathrm{WCH}$ of Jatiluwih. This area is an agricultural area with beautiful rice terraces, with the background of a line of mountains in the north, and a sea view in the south. In this area, Balinese traditional art has developed, and the people's houses have Balinese architecture. It is the tradition in the community that the practice of the community life is according to the Hindu tradition of most of its population. In this area there are Agricultural Training Center and SelfSupporting Village (P4S) "Somya Pertiwi" with farmer groups who use an organic farming system. Based on the characteristics of Mengesta Village as described above, through this study an educational tourism was developed.

Educational tourism is a program which combines the elements of tourism activities with educational content in them. This program is very suitable for those who want to travel to tourist objects while learning something there. With such characteristics, this program is very suitable with schools that develop and educate the students. In addition to the learning program in class, an 
educational tourism program is proven to be effective in increasing teaching patterns and socialization among the students [6] [7]. The tour activity in the educational tourism tour will have a broader impact on the economic development in the area since tourist centers that are developed involve the community directly. The community participation can be done in two ways, which are the participation in decision making and in sharing the benefits of the tourism [8].

Educational tourism being developed in Bali especially needs to take into account local genius elements that are practiced by the people in the society. One of the elements is the development of tourism based on Tri Hita Karana (THK) concept. The THK concept is one of guidelines in the Balinese life from generation to the next generation and can be used as featured in ensuring the community's commitment for developing the tourism education business [9] [10]. THK has the meaning of maintaining the harmonious and peaceful relationships human has with God, other human fellows, and the environment in order to live a balanced life. In developing tourism based on THK some aspects are required to support it. The aspects are as follows (a) parahyangan aspect that consists of a space/ a region for holy places/for worship; (b) pawongan aspect consisting of space/region for humans and the community; and (c) palemahan aspect consisting of space'region for farming and conservative land such as ravines, steep river banks or mountains rivers, river flood plains, mounts/ hills and forests [1]. Therefore, the problem formulated in this research is how the impact of the development of Tri Hita Karana-based education tourism in WCH of Jatiluwih region?

\section{METHODS}

This study was a descriptive and qualitative research. The sample consisted of 60 community members involved as the learning resource persons in developing the educational tourism and community figures in Mengesta Village, Penebel, Tabanan. The sample was selected by purposive sampling technique, considering the learning resources and the number of sample members, that is, agricultural group with 15 members, and women farmer group with 15 members, art group with 15 members, and a group with other community members with 15 members.

The data collected in this study were the impacts of educational tourism development on the improvement of the quality of community life. The community life quality covered the improvement of the community social life and the improvement of the local economy. The community life quality measured consisted of perception of the community about the development of the educational tourism, the preservation of agricultural land, and the existence of tradition, custom and culture, the participation of the community in the implementation of the educational tourism, home stay, the impact on the community social life, the impact on the preservation of environment, education and training for the community, and the participation of private organizations in management. Increase in the local economy was measured by looking at the average of the increase in income of the community from the time before the and after the implementation of the educational tourism.

The data were collected by observation and questionnare. The questionnaire on perception of the community used Likert scale with the scales ranging from 1 to, consisting of 10 items in the form of statements. Score 1 stands for strongly disagree; score 2, disagree; score 3, cannot decide; score 4, agree; score 5 , strongly agree. The questionnaire on community income used a closed questionnaire type by giving options of income based on a range. The field observation used an observation guide, done by making an observation directly to the community.

Data analysis was done descriptively and by using qualitative analysis. The descriptive analysis was done by counting the mean score of the perception of the community obtained based on the questionnaire given. The categories of perception were converted as follows.

Difference per category $=$

$\frac{\text { Skortertinggi-Skorterrendah }}{\text { banyakkategori }}=\frac{5-1}{5}=0.8$

Thus, the following conversion guide is obtained as shown in table 1.

TABLE 1.GUIDE FOR CONVERTING THE COMMUNITY'S PERCEPTION [11]

\begin{tabular}{|l|l|}
\hline Mean Score $(\bar{X})$ & Caegory \\
\hline $4,2 \leq \bar{X}$ & Very positive \\
\hline $3,4 \leq \bar{X}<4,2$ & Positive \\
\hline $2,6 \leq \bar{X}<3,4$ & Moderate \\
\hline $1,8 \leq \bar{X}<2,6$ & Negative \\
\hline $1,0 \leq \bar{X}<1,8$ & Very negative \\
\hline
\end{tabular}

Improvement in the community's economy is calculated based on the number of people who enjoy an average income increase per month, as seen from the condition before and after the 
implementation of the educational tourism in their area. Qualitative analysis was done through a series of activities, that is, data reduction, data display, data interpretation, and conclusion drawing. In the analysis of these data, the data were grouped into certain categories, concepts, proportion, or themes. After that, an interpretation was made, by giving a meaning and explaining the categories, patterns and by finding the relations in an effort to answer research questions.

\section{RESULT AND DISCUSSION}

From the result of questionnaires that were distributed to the respondents, the perception of the community toward the implementation of the educational tourism program based on Tri Hita Karana (THK) in Mengesta Village, the following result as shown in table 2 was found.

TABLE 2. PERCEPTION OF THE COMMUNITY TOWARD THE IMPLEMENTATION OF EDUCATIONALTOURISM.

\begin{tabular}{|l|c|l|}
\hline $\begin{array}{c}\text { Mean Score } \\
(\bar{X})\end{array}$ & $\begin{array}{c}\text { Nummber of } \\
\text { Respondents (persons) }\end{array}$ & \multicolumn{1}{|c|}{ Category } \\
\hline $4,2 \leq \bar{X}$ & 45 & Very positive \\
\hline $3,4 \leq \bar{X}<4.2$ & 8 & Positive \\
\hline $2,6 \leq \bar{X}<3.4$ & 7 & Moderate \\
\hline $1,8 \leq \bar{X}<2.6$ & 0 & Negative \\
\hline $1,0 \leq \bar{X}<1.8$ & 0 & Very negative \\
\hline Total: & $\mathbf{6 0}$ & \\
\hline
\end{tabular}

Based on table 2, it can be seen that the number of respondents who had the minimal positive perception was $53(88 \%)$. There were 7 respondents who had an undecided perception and none had negative and very negative perceptions.

Improvement in the local economy/the people's incomes was found based on the questionnaire and is related to the income received before and after the implementation of the educational tourism based on THK. The recap of the result of questionnaire on the people's income is presented in table 3 .

Based on table 3, it can be seen that after the implementation of the THK-based Educational tourism that has lasted for about 2 years, no respondent's income is below 1 million rupiahs per month. However, none has reached income above 4 million per month, except 1 respondent who, before the implementation of the educational tourism had an income above 1 million per month. The distribution of the increase from before to after the implementation can be explained as follows. 5 respondents were in Range No. 5 and got an increase of income to Range No. 4. 25 respondents were in Range No. 4 and got an increase to Range No..3. 3 respondents were in Range No. 3 and got an increase to Range No.2. Thus, 33 respondents (55\%) got an increase of income from before to after the program implementation.

TABLE 3. RECAP OF THE AVERAGE OF INCOME OF THE COMMUNITY PER MONTH

\begin{tabular}{|c|c|c|c|}
\hline \multirow[t]{2}{*}{ No. } & \multirow{2}{*}{$\begin{array}{c}\text { Income Range }(X) \\
\text { In millions of Rupiahs) }\end{array}$} & \multicolumn{2}{|c|}{ Number (persons) } \\
\hline & & Before & After \\
\hline 1. & $4 \leq X$ & 1 & 1 \\
\hline 2. & $3 \leq X<4$ & 4 & 7 \\
\hline 3. & $2 \leq X<3$ & 5 & 28 \\
\hline 4. & $1 \leq \mathrm{X}<2$ & 45 & 25 \\
\hline 5. & $\mathrm{X}<1$ & 5 & 0 \\
\hline & Total: & 60 & 60 \\
\hline
\end{tabular}

Based on the result of the study $i$ the quality of life of most of the people was in positive and very positive categories. On a close observation, in the implementation of the program of the educational tourism especially in Mengesta village, the people who lived in the area were really empowered optimally. This empowerment occurred starting from the centers of learning resources, as the owners of learning resources, as the owners of the infrastructures and facilities that supported the implementation of the educational tourism, as the guides in the tourism destination. This agrees with the result of study done by [12] who state that the implementation of tourism has to involve the participation of the people around the tourist destination maximally.

Attractions presented were done by using learning group system: the groups were art group, farmer group, and agricultural crop processing group (agricultural women group). Every group has got its clear and transparent business operational regulation, and the division of business income was based on the agreement among the group members with this way of implementation, each group member got even business income. The quality of social life among the group members was created well and was open. This is one element of the concept of Tri Hita Karana that is related to keeping a harmonious relationship among human beings [1].

Simultaneously with the implementation of the educational tourism program in this area, the awareness and quality of the people's understanding of the importance of keeping the cleanliness of the environment increased from time to time. The habit that started to develop was the habit of keeping the house environment clean, because of the tourist visit to their houses. In addition, there was a business of producing organic fertilizer by using waste from cattle and agricultural waste, so that it could reduce environmental pollution. The use of organic fertilizer agriculture could improve the quality of the worse 
soil condition that was caused by the use of inorganic fertilizer in a long time [13]. There was an increase in the agricultural crops, especially rice, the best commodity of this area. Rice cultivation with organic system increased the rice quality produced and increased the sale price of rice in this area [13]. Since the application of organic agricultural system, birds (kokokan/herons) started to come, who had never appeared in this area. The presence of the birds, in addition to helping the farmers in exterminating insects, it also added the beauty of the natural panorama in this area. So, there were efforts to preserve the environment, which is the manifestation of the THK concept of keeping the harmonious relationship with the natural environment.

In the attraction of the tourist visit to the people's houses, the tourists were presented an attraction about the tradition of the people according to Hinduism. The tourists watched the way to make canang sari or offerings for the Hindu rituals which are performed everyday. The tourists could learn how to make canang/ offerings, and to learn how to cook traditional Balinese food. The people kept the cleanliness of the shrines (merajan) since the tourists usually saw all the buildings in the people's house environment. The religious traditions kept being preserved by performing religious rituals before and after rice harvest, as the manifestation of gratefulness to God who has blessed the crops in abundance. This shows the quality of the spiritual life which became better and better. This is the manifestation of the THK concept of keeping a harmonious relationship with God.

There was an increase in the local economy, that is, the average increase of the people's income (especially that increase of the learning resource persons' income) from before to after the implementation of the educational tourism program. This occurred because of the additional source of income that the people got as the impact of the tourist visit to the area, both domestic and foreign tourists. With the presence of tourist visit, the local people could sell their organic agricultural products of good quality such as red rice, black rice, and brown/yellow rice which have never/seldom been cultivated in other areas. In addition, the people in this area could also sell processed agricultural products such as special food from this area by presenting rice in various colors.

\section{CONCLUSION}

The implementation of the Tri Hita Karana-based educational tourism in Mengesta village, which is located in the World Cultural Heritage area of Jatiluwih, has positive impacts on the quality of the community life in this area. The community life as seen from social community life is categorized in the "positive" minimal qualification and the improvement in the local economy as seen from the number of people (the learning resource person group) who have got an increase in their average income per month, that is, $55 \%$ of all the respondents. The more efforts made by the people are related to the Tri Hita Karana concept in the community life. This is seen from the efforts to preserve the environment, the harmonious relationship among human beings, and the religious life which becomes better. Beside the positive impacts, there are also negative impacts that are resulted from the implementation of the educational tourism that needs a further solution from various people. The negative impacts, among other things, are social jealousy from people who have not been able to enjoy the economic impact that is resulted and the presence of customary binding rules that often become an obstacle in the implementation of the tourism.

\section{ACKNOWLEDGEMENT}

The author would like to thank the Ministry of Research, Technology and Higher Education (Kementrian Ristekdikti) for the financial support, and the Rector and the Institution of Research and Community Service (Lembaga Penelitian dan Pengabdian pada Masyarakat) of Undiksha for the support in the implementation of this research from the writing of the proposal stage to the research implementation.

\section{REFERENCES}

[1] N.N. Parwati and Trianasari, "Educational Tourism Based on Tri Hita Karana," Binus Bus. Rev., vol. 7(3), no. November 2016, pp. 307-314, 2017.

[2] W. Nuryanti, "Heritage and postmodern tourism," Ann. Tour. Res., vol. 23, no. 2, pp. 249-260, 1996.

[3] J. Swarbrooke, "Development and Management of Visitor Attractions," Dev. Manag. Visit. Attract., pp. 371-393, 2002.

[4] A. M. . b Abubakar, B. H. T. . Shneikat, and A. . Oday, "Motivational factors for educational tourism: A case study in Northern Cyprus," Tour. Manag. Perspect., vol. 11, pp. 58-62, 2014.

[5] Suhartini, "Kajian Kearifan Lokal Masyarakat dalam Pengelolaan SDA dan lingkungan," Semin. Nas. Penelitian, Pendidik. dan Penerapan MIPA, pp. 206-218, 2009.

[6] M. A. H. Bhuiyana, R. Islam, C. Siwar, and S. M. Ismail, "Educational tourism and forest conservation: Diversification for child education," in Procedia - Social and Behavioral Sciences, 2010, vol. 7, pp. 19-23.

[7] J. Whitfield, L. D. A. N. Dioko, D. Webber, and L. Zhang, "Attracting convention and exhibition attendance to complex MICE venues: Emerging data from Macao," Int. J. Tour. Res., vol. 16, no. 2, pp. 169-179, 2014.

[8] D. J. Timothy and S. W. Boyd, "Heritage Tourism in the 21st Century: Valued Traditions and New Perspectives," J. 
Herit. Tour., vol. 1, no. November, pp. 1-16, 2006.

[9] H. Schein Edgar, "The learning leader as culture manager," in Classic readings in organizational behavior, vol. 20, 1992, p. 228-.

[10] F. P. Simbolon, "The Impact of Relationship Marketing Strategy in Indonesia Retail Industries," Binus Bus. Rev., vol. 7, no. 2, p. 143, 2016

[11] G. Norman, "Likert scales, levels of measurement and the 'laws' of statistics," Adv. Heal. Sci. Educ., vol. 15, no. 5, pp. 625-632, 2010.

[12] A. M. Abubakar, B. H. T. Shneikat, and A. Oday, "Motivational factors for educational tourism: A case study in Northern Cyprus," Tour. Manag. Perspect., vol. 11, pp. 58-62, 2014.

[13] T. Siegmeier, B. Blumenstein, and D. Möller, "Farm biogas production in organic agriculture: System implications," Agric. Syst., vol. 139, pp. 196-209, 2015. 